\title{
THE RELATIONSHIP BETWEEN R\&D EXPENSES AND THE ABNORMAL RETURN IN BRAZILIAN FIRMS
}

\author{
AMABELE M. OLIVEIRA ${ }^{1}$ \\ (iD) https://orcid.org/0000-0001-9780-3560 \\ VINÍCIUS M. MAGNANI \\ (iD https://orcid.org/0000-0002-0069-954X \\ JÚLIA P. TORTOLI ${ }^{3}$ \\ (iD) https://orcid.org/0000-0003-1703-498X \\ ANELISE K. P. FIGARI ${ }^{4}$ \\ (D) https://orcid.org/0000-0002-9209-5873 \\ MARCELO A. AMBROZINI ${ }^{3}$ \\ (iD) https://orcid.org/0000-0003-0933-6064
}

To cite this paper: Oliveira, A. M., Magnani, V. M., Tortoli, J. P., Figari, A. K. P., \& Ambrozini, M. A. (2019). The relationship between R\&D expenses and the abnormal return in Brazilian firms. Revista de Administração Mackenzie, 20(5). doi:10.1590/1678-6971/eRAMF190106

Submissão: May 12, 2018. Aceite: Apr. 12, 2019.

\footnotetext{
KPMG Brazil, Ribeirão Preto, SP, Brazil.

2 Centro Universitário Moura Lacerda (CUML), Ribeirão Preto, SP, Brazil.

3 Universidade de São Paulo (USP), Ribeirão Preto, SP, Brazil.

4 Universidade Federal do Paraná (UFPR), Curitiba, PR, Brazil.
}

\section{(cc) BY This is an open-access article distributed under the terms of the Creative Commons Attribution License.}

\footnotetext{
This paper may be copied, distributed, displayed, transmitted or adapted if provided, in a clear and explicit way, the name of the journal, the edition, the year and the pages on which the paper was originally published, but not suggesting that RAM endorses paper reuse. This licensing term should be made explicit in cases of reuse or distribution to third parties. It is not allowed the use for commercial purposes.

Este artigo pode ser copiado, distribuído, exibido, transmitido ou adaptado desde que citados, de forma clara e explícita, o nome da revista, a edição, o ano e as páginas nas quais o artigo foi publicado originalmente, mas sem sugerir que a RAM endosse a reutilização do artigo. Esse termo de licenciamento deve ser explicitado para os casos de reutilização ou distribuição para terceiros. Não é permitido o uso para fins comerciais.
} 


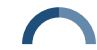

Amabele M. Oliveira, Vinícius M. Magnani, Júlia P. Tortoli, Anelise K. P. Figari, Marcelo A. Ambrozini

\section{ABSTRACT}

Purpose: This study aims to analyze the relationship between the abnormal return and R\&D expenses in Brazilian public firms.

Originality/value: The determinants of firms' abnormal return provide information relevant to investors' decision-making. In this context, we verified whether the innovation, measured by $R \& D$ expenses, could be a key factor for the abnormal returns in Brazilian firms.

Design/methodology/approach: We analyzed Brazilian public firms, from 2009 to 2016, by panel data regressions, in a sample composed by 1,597 firm-year observations. We collected information about $R \& D$ expenses in the footnotes. When a firm only mentioned about R\&D expenses but did not disclose spent value in the Income Statement, we consider that the firm did not invest in the period and we attribute zero as a value. We highlighted that few firms mentioned R\&D expenses in their footnotes and/or declared that they invested in R\&D, only 44 firms in all sample, pointing the importance of better disclosure practices of these investments. Findings: The results demonstrate a negative and statistically significant relationship between innovation and the abnormal return. That is, current $\mathrm{R} \& \mathrm{D}$ expenses lead to a lower current abnormal return. It could be linked with the fact that $R \& D$ expenses tend to produce returns just in longer periods, demanding more time to recover these investments, due to their complex characteristics related to accounting measurement of $\mathrm{R} \& \mathrm{D}$ expenses. Consequently, an abnormal return could be perceived only in subsequent periods.

\section{KEYWORDS}

Abnormal return. Intangibles assets. Innovation. R\&D expenses. Brazilian financial market. 


\section{INTRODUCTION}

In recent years, the nature of business and the concept of what the competitive advantages are changed significantly. In the industrial economy, "the firms would create value from tangible assets, by processing the raw material into finished products" (Kaplan \& Norton, 2000, p. 12) and the competitive advantages, such as economies of scale and capital contributed efficiently for the firms' value generation (Pulic, 2004).

Nowadays, in the era of knowledge, the advances in information technology and the intensification of competition among firms contribute to the competitive advantage is further linked to creation processes, which depend on intangible assets that are not recognized in the firms' balance sheets (Beattie, McInnes, \& Fearnley, 2004).

Tangible assets are seen as commodities, insofar as the traditional company, intensive in fixed assets, aimed to explore economies of scale, cannot sustain the old competitive advantages and growth rates too longer. It happens due to the fact that economies of scale are characterized by excessive product standardization, which exhausted over time. Moreover, intangible assets are taking place to provide abnormal returns and competitive advantages (Perez \& Famá, 2006).

Among several intangible assets which contribute greatly to the obtainment of important competitive advantages in the long run and which add value to a company, are the investments in research and development (R\&D). Nonetheless, there is great recognition and measurement difficulty of these assets by the firms, mainly when they are created or developed internally (Perez \& Famá, 2006).

Considering the Brazilian context, in the last two decades, some policies and incentives focused on science, technology and innovation are developed (Turchi \& Morais, 2017). As a policy to encourage technological innovation, the Brazilian government created federal public institutions, as the Fund for Studies and Projects (FINEP) and the Brazilian Development Bank (BNDES), which act in the promotion of innovation through mechanisms for financing organizations. The government also instituted in Law no. 11,196 of 2005, known as the Good Law (Lei do Bem), tax incentives for organizations investing in $R \& D$, by allowing real estate companies to deduct R\&D investments from the tax base (Menezes, Komatsu, Lucchesi, \& Ferrario, 2014). There is also the mandatory investment in $\mathrm{R} \& \mathrm{D}$ in regulated companies, the National Electrical Energy Agency (Aneel) and National Oil Agency (ANP). 
However, most of these incentives are centralized in a few large organizations, especially in the private sector. Consequently, there is a lack of innovations in $\mathrm{R} \& \mathrm{D}$ investments, discouraging the competition and the adoption of modern managerial practices (Menezes et al., 2014).

According to accounting standards in Brazil (Comitê de Pronunciamentos Contábeis - CPC, 2010), the recognition of intangible assets generated internally takes place in two stages, research and development. The expenses with development can be capitalized if, and only if, the company is able to demonstrate the investment characteristics described in the CPC 04 which regards intangible assets. On the other hand, the research expenses, due to regulatory concerns and the accounting conservatism, are discharged directly as an expense of the period in the Income Statement, which does not allow the company to show that there is an asset with great potential of future cash generation being internally developed.

In this sense, quantifying the return of $R \& D$ and innovation activities is a complex task, mainly due to three reasons. The first one, as pointed by Pavitt, Steinmueller, Pettigrew, Thomas, and Whittington (2002), it is very difficult to assess the value of technological activities and inventions before their incorporation in products and its provision in the market due to the high level of uncertainty in the probability of its scientific success.

The second reason is that, even when the activities in $R \& D$ result in a marketable product, it is complex to verify the result of this investment, due to the gap between the period of expenses on innovation and the real impact from these expenses which could be perceived only in longer periods (Ambler, 2003; Gupta, 2011; Lev, 2001; Upton, 2001).

Finally, the third reason, Hall (2000) mentions that it is a complex process because other factors could affect the firm's returns, not only isolated $\mathrm{R} \& \mathrm{D}$ investments.

Camargo, Zanin, Diel, and Bianchet (2016) identified a negative relationship between R\&D expenses and firms' financial returns, in G-20 firms, due to the occurrence of returns peaks. In complement, Silva, Klotzle, Pinto, and Motta (2018) showed that firms with greater industry-adjusted R\&D intensity are less risky than their counterparts. Further, the evidence also demonstrated that these firms also provide more information to the market about their innovation projects, mitigating a potential undervaluation.

The aim of this study is to analyze the relationship between the abnormal return, measured by the difference between the actual return and the expected one, and the R\&D expenses which are not activated by accounting, a proxy for innovation. For this purpose, we analyzed whether R\&D expenses are a key factor to explain firms' abnormal return in Brazil, from 2009 to 2016. 
We highlighted that only 44 firms mentioned R\&D expenses in their footnotes and/or declared investing in R\&D in the period, pointing out the importance of better disclosure practices. Chander and Mehra (2011) affirm that intangible assets became a key part of the process of value creation for any firm, requiring external communication to the stakeholders. In addition, Silva, Klotzle, Pinto, and Motta (2018) found evidence that firms which provide more information to the market about their innovation projects tend to mitigate their potential undervaluation in, approximately, $40 \%$.

Through panel data regressions, our findings demonstrate a negative and statistically significant relationship between innovation and abnormal returns. That is, an investment from current $R \& D$ expenses leads to a lower current abnormal return. This evidence is robust to macroeconomic effects, by controlling Brazilian's gross domestic product (GDP) growth.

Our study seeks to help investors' decisions, providing evidence that $\mathrm{R} \& \mathrm{D}$ expenses tend not to provide abnormal returns in the short run, due to their complex characteristics related to accounting measurement. That is, these investments could demand more time to be recovered and, consequently, abnormal returns could be perceived only in subsequent periods, when in fact those expenses will become innovations, by increasing in revenues, profits and the firm value.

Additionally, this study seeks to provide support to innovative firms which are interested in assessing the economic return of their innovation activities, including the baseline survey expenses, which are considered non-allocable costs by the traditional accounting. It is worth highlighting that, according to the analysis carried out, there are still a few studies about the theme which approaches, specifically, the Brazilian stock market (Honorato, 2008; Kayo, 2002).

Finally, our paper is divided into other four sections, in addition to this introduction, which are: a theoretical review and hypothesis development, methods and data, results and discussions and, concluding remarks.

\section{THEORETICAL REVIEW AND HYPOTHESIS DEVELOPMENT}

The intangible assets are one of the most complex and challenging areas in accounting (Hendriksen \& Van Breda, 1999). In accordance with CPC 04, the intangible asset is an identifiable non-monetary asset that is not physical in nature (CPC, 2010). 
According to Upton (2001), intangible assets can be defined as nonphysical resources, generators of probable future economic benefits for a firm, which have been acquired by the exchange or even internally developed based on identifiable costs, which have limited life span, have their own market value and which do not belong or are controlled by the firm. The author also states that the intangible assets can be all the elements of a company which exists besides both the monetary and the tangible assets.

Nonetheless, the first great restriction to the use of intangible assets, mainly when created or developed internally, as R\&D investment, secret formulas, trademark and technological know-how, brands, goodwill, is in their recognition and measurement by the firms, due to subjectivity in measuring their values and the difficulty in quantifying the returns of innovation activities (Perez \& Famá, 2006). In general, the existing financial statements only recognize the intangible assets acquired from external providers (Upton, 2001).

Such accounting treatment given to the intangible assets created or developed internally leads us to naturally question the efficiency of the traditional accounting system - essentially structured for an industrial era, allocating expenses with raw material and salaries to product, process or activity costs, but considering as non-allocable costs the research and development expenses - in capturing and representing the economic reality of the firms' commercial activities by the financial statements. As a result, the financial statements are far from the economic value of the firms, reducing, therefore, the informational power and the use of these statements (Lev, 2001; Reilly \& Schweihs, 1998; Zanoteli, Amaral, \& Souza, 2015).

The objection imposed by the traditional accounting to the enhanced recognition of the intangible assets generated internally leads to the undervaluation of the shares of the intangible-intensive firms in the capital market, mainly in the earlier periods, when the firms have not reached significant profitability levels yet due to the great disbursement of financial funds. It causes a certain level of skepticism in the investors regarding the returns on investments (Aboody \& Lev, 2000; Chan, Lakonishok, \& Sougiannis, 2001; Daniel \& Titman, 2006).

According to Chan et al. (2001), stock prices are undervalued in R\&Dintensive firms in the early periods, which tend to have poor past earnings due to preliminary spending on basic research. However, in subsequent periods, they identified abnormal positive returns to investors, confirming that $\mathrm{R} \& \mathrm{D}$ intensity is positively associated with return volatility.

Moreover, the lack of value incorporation of these intangible assets tends to affect cost of capital, since the accounting numbers do not reflect a 
great parcel of the intangible assets, the intensive R\&D firms may seem more leveraged than they really are, facing greater debt cost on the part of their potential creditors and, in most cases, the self-funding of the R\&D activities by the company itself is necessary, which, in fact, is negatively perceived by the most conservative shareholder who will receive fewer dividends due to fund withholding to subsidize the R\&D and innovation activities (Chan et al., 2001; Gupta, 2011).

Furthermore, the greater presence of intangible assets not capitalized tends to jeopardize the investors' and creditors' book-to-market (Chan et al., 2001; Donnelly, 2014; Hirschey \& Weygandt, 1985). In addition, since innovation is preliminarily acquired by investments in intangible assets and is treated as compensation in relation to the company's performance, a tendency is to increase the dislocation between the book value and the market value of the company, that is, the more innovation, the greater the market value and the more obvious is this distance between both values (Lev, 2001).

The lack of proper accounting information disclosure of internally generated intangible assets leads to the increase of information asymmetry, since the research expenses are dealt with as expenses and, therefore, not activated in the firms' financial statements, and provoke the non-disclosure of information on the value variations and productivity, making the investors' understanding of R\&D investment policy (Aboody \& Lev, 2000).

The non-capitalization of research expenses substantially contributes to the information asymmetry between managers and investors, and the first ones tend to explore this asymmetry to earn with the inside information trade (Aboody \& Lev, 2000; Barth, Kasznik, \& McNichols, 2001).

Regarding the innovation assets, several authors highlight a company's innovative ability, which outbreaks the discovery of new products, services or processes, as an essential intangible competence in the search for higher performance (Chaney \& Devinney, 1992; Dosi, 1988; Gopalakrishnan, 2000; Motohashi, 1998; Tidd, 2001) and in sustaining the competitive advantage (Besanko, Dranove, Shanley, \& Schaefer, 2009).

Tidd, Bessant and Pavitt (2005) argue that the complexity related to R\&D investments tends to make activities costly and risky so that measuring R\&D performance is relevant for firms. Lazzarotti, Manzini, and Mari (2011) point out some reasons that managers could be concerned about this performance measurement: 1. the market has become more dynamic and more competitive, as the customers' needs are changing quickly; 2 . there is a variety of products and services that are been produced; and, in last, 3. there is an increase of complexity in knowledge incorporated into products and services. 
Werner and Souder (2016) also determine that the choice for an R\&D performance metric depends on users' needs for the comprehensiveness of this measurement, the type of $\mathrm{R} \& \mathrm{D}$, the available data and the amount of effort allocated to do it. They also demonstrated that combining several types of quantitative and qualitative measures tends to be more effective, however, it is also more complex and costlier.

Perez and Famá (2004) investigated whether intangibles may be responsible for greater value creation for shareholders. The authors concluded that intangibles can differentiate companies and create value, stimulating growth through new investments and contributing to increasing shareholder wealth.

The theoretical rationale which supports this view is called Resource-Based Theory (RBT), which is a strategy perspective that explains the competitive advantage from the company rare, valuable and costly resources of imitating or substituting and it signals that the ownership of these resources can lead an organization to obtain abnormal profits and, ultimately, are responsible for the value creation of a company (Barney, 1991).

Villalonga (2004, p. 206) points out "intangible resources as the main sustainability engines of the performance differences among firms". In this sense, several empirical studies found positive effects from innovation on firms' financial performance (Decker, Ensslin, Reina, \& Reina, 2013; Hall, 1986; Kothari, Laguerre, \& Leone, 1998; Klomp \& Van Leeuwen, 2001; Mansfield, 1962; Oliveira, Schossler, Campus, \& Luce, 2014; Perez \& Famá, 2006). In complement, Figari, Tortoli, Silva, and Ambrozini (2017) found evidence that cumulative R\&D expenses contribute to increasing firms' value (measured by book-to-market index) in Brazilian public firms. Among them, Brito, Brito, and Morganti (2009) evinced that there was no significant relationship between the innovation and financial performance variables.

Azevedo and Gutierrez (2009) found a positive relationship between $\mathrm{R} \& \mathrm{D}$ expenses and the long-term growth of the firms from the New York Stock Exchange (NYSE). This study contributed to understanding the reason why American firms continuously invest in R\&D. It could be linked with the fact that the development of products, services, and new technologies tend to provide abnormal returns by long-term growth. Such results are aligned to Chan, Martin, and Kensinger (1990), and Lee and Shim (1995).

Finally, Camargo et al. (2016) analyzed firms from G-20 countries, related to manufacturing and technology industries, from 2011 to 2015. They found a negative relationship between R\&D expenses and organizational performance, measured by return on assets (ROA). They concluded that this relationship could be attributed by the fact that the firms presented 
peaks of return in the period analyzed. This evidence also corroborates with Cho and Pucik (2005).

We present our research hypothesis, based on previous studies above:

- H0: Brazilian firms which invest in $\mathrm{R} \& \mathrm{D}$ offer greater abnormal returns.

\section{METHODS AND DATA}

We collected data from a population of public firms (Brasil, Bolsa, Balcão, known as B3), from 2009 to 2016, by Economatica ${ }^{\circledR}$ database. From this population, we applied some filters, with the subsequent exclusion of the following firms: 1 . financial and insurance institutions, due to their specific traits which could distort the results and; 2 . firms which did not have available data. After those exclusions, the final sample totaled 1,012 firmyear observations of several economic industries, by unbalanced panel data.

We analyzed the final sample by applying the multiple linear regression model, according to Equation (1):

$$
R A=\beta_{0}+\beta_{1} \cdot I N O V_{i, t}+\beta_{n} \cdot \operatorname{CONTR}_{i, t}+\varepsilon
$$

in which:

$R A=$ abnormal return (dependent variable); $I N O V_{i, t}=$ ratio of R\&D expenses (interest independent variable); $\mathrm{CONTR}_{i, t}=$ control independent variables (size, current liquidity, indebtedness, and profitability);

$\varepsilon=$ regression's error.

The dependent variable is the abnormal return $(R A)$ :

$$
R A=R_{E}-\bar{R}
$$

in which $R_{E}=$ actual return and $\bar{R}=$ expected return.

The calculation of the actual return is described in Equation (3):

$$
R_{E}=\frac{P_{t+1}-P_{t}}{P_{t}}
$$

in which $P_{t}=$ share price in time $t$ (available on Economatica ${ }^{\circledR}$ database). 
Abnormal return is widely used in Capital Asset Pricing Models (CAPM) studies since the seminal proposition of Jegadeesh and Titman (1993). In Brazil, Mussa, Rogers, and Securato (2009) performed a study that empirically tested different expected return models, among them the CAPM models, the Fama and French 3-factor model (1993) and the 4-factor model of Jegadeesh and Titman (1993). In all of these methodologies, Mussa et al. (2009) analyzed abnormal returns. For determining the expected return of individual securities, the CAPM can be characterized by the Equation (4) (Ross, Westerfield, Jaffe, \& Lamb, 2015):

$$
\bar{R}=R_{F}+\beta\left(\bar{R}_{M}-R_{F}\right)
$$

in which

$\bar{R}=$ a security expected return calculated by the CAPM;

$R_{F}=$ risk-free rate;

$\beta=$ security beta coefficient, which measures the systematic risk of the company;

$\left(\bar{R}_{M}-R_{F}\right)=$ difference between the market expected return and the free risk rate, or market risk premium.

Several studies around the world showed that CAPM is the most widely used model by market professionals and financial analysts. Keck, Levengood, and Longfield (1998) conducted a survey of graduates of the University of Chicago Business School. They found that, among other objectives, CAPM model is used in practice. In a CFO survey of 392 American and Canadian companies, Graham and Harvey (2001) found that CAPM model is the most popular method of estimating the cost of equity in the United States, being used frequently by $73.5 \%$ of respondents. In Brazil, Argolo, Leal, and Almeida (2012), and Benetti, Decourt, and Terra (2008) also found evidence that supports the CAPM model, as a true benchmark for financial analysts.

A rate considered risk free is the one in which there is no uncertainty regarding the amount to be received by the investor at the end of the investment period. That is, a risk free asset must have a fixed return without the non-payment probability by the borrower at its due date (Sharpe, Alexander, \& Bailey, 1999). In this paper, we used the interest rates for savings accounts as risk-free rate, as previous studies (Barros, Silveira, \& Famá, 2003; Mussa et al., 2009; Mussa, Famá, \& Santos, 2012; Rogers \& Securato, 2009; Silva, Pinto, Melo, \& Camargos, 2009). Silva et al. (2009) highlighted that savings accountings is an application in which historical returns have lower standard deviations than other financial investments. Moreover, the Selic rate could also be applied, however, this rate presented 
relatively high values in the period, which could even be higher than the return expected by the market portfolio in a few years, affecting the premium for market risk.

In the CAPM model, the beta $(\beta)$ coefficient is used as a systematic risk parameter (or non-diversified, arising from uncertainties inherent to the economic, political and social context) underlying the traded assets. When an asset presents $\beta>1$, it reveals that the price of this asset tends to be altered with greater proportion to the market changes as a whole and, conversely, when the $\beta<1$, it indicates that the asset has prices which are less volatile than the market. Thus, the assets with higher betas have more high systematic risks and, consequently, greater expected returns (Oliveira, Karvalho, Roma, \& Melo, 2011).

Several previous studies (Blume \& Friend, 1973; Rogers \& Securato, 2009; Sanvicente, 2015), both in Brazil and internationally, estimated the beta coefficient of the CAPM model with monthly regressions over the 60-month period, as proposed by some large consulting firms, including Standard \& Poor's. We obtained the 60 -month beta $(\beta)$ coefficient by Economatica ${ }^{\circledR}$ database.

As expected return by the market portfolio $\left(\bar{R}_{M}\right)$, we used the average return of the last ten years (from December 2007 to December 2016) of the firms listed at the Index of the Bolsa de Valores de São Paulo - São Paulo Stock Exchange (Ibovespa). Several previous evidences demonstrated the application of Ibovespa as a market portfolio (Araújo, Oliveira, \& Silva, 2012; Araújo, Fajardo, \& Tavani, 2006; Fellet, 2016; Matos \& Rocha, 2009; Rogers \& Securato, 2009; Sanvicente, 2015; Silva et al., 2009; Silva, Pinto, \& Melo, 2012; Tambosi, Garcia, \& Bertucci, 2007). It is important to clarify that not necessarily the period of regressions to obtain the beta coefficient should coincide with the average return period of the market portfolio, as it can be underlined by the previous one.

We use the discrete return $\left(R_{E}\right)$ of the shares subtracted from the expected discrete return $(\bar{R})$ by the CAPM. The continuous return could have been used for the actual and expected returns, but that would not alter the research results, since the dependent variable $(R A)$ of this paper is the difference between both returns (actual minus the expected one), according to the Equation (3).

The interesting variable, expressed by the innovation index, $I N O V_{i, t^{\prime}}$ is described in Equation (5):

$$
\operatorname{INOV}_{i, t}=\sum \frac{G P_{(i, t)}}{A T_{(i, t)}}
$$


in which $I N O V_{I, t}$, innovation index, corresponding to the sum of the division of research expenses and each company's total assets in each year, $\frac{G P_{(i, t)}}{A T_{(i, t)}}$, for the period from 2009 to 2016.

The $R \& D$ expenses, which are discharged directly in the income statement, were collected from the firms' footnotes. When the company only mentions the research expenses but does not present the amount of research expense, we took into account that the firm did not invest in the period and we assign it the value zero.

The independent control variables are: company size $\left(\operatorname{Tam}_{i, t}\right)$, current liquidity $\left(\right.$ LiqCorr $\left._{i, t}\right)$, indebtedness $\left(\right.$ Endiv $\left._{i, t}\right)$ and profitability $\left(\right.$ Rent $\left._{i, t}\right)$, measured by ROA. We collected these variables through Economatica ${ }^{\circledR}$ database.

\section{RESULTS AND DISCUSSION}

In Figure 4.1, we present the descriptive statistics for our sample, in order to characterize the firms, considering 2009 to 2016.

\section{(Figure 4.1)}

DATA DESCRIPTIVE STATISTICS

\begin{tabular}{lcccccc}
\hline & $\begin{array}{c}\text { Abnormal } \\
\text { return (RA) }\end{array}$ & Innovation & Size & $\begin{array}{c}\text { Current } \\
\text { liquidity }\end{array}$ & Indebtedness & Profitability \\
\hline Average & 0.0489 & 0.0011 & 14.9423 & 1.8384 & 4.9228 & 3.6736 \\
\hline Median & -0.0795 & 0.0000 & 14.9890 & 1.5840 & 4.9035 & 3.5449 \\
\hline Standard deviation & 0.6466 & 0.0101 & 1.7045 & 1.1422 & 1.1244 & 6.7824 \\
\hline Maximum & 5.5467 & 0.3595 & 20.6181 & 7.9237 & 9.9676 & 20.1394 \\
\hline Minimum & -1.1275 & 0.0000 & 9.4267 & 0.0127 & -1.1945 & -10.9856 \\
\hline Observations & 1597 & 1597 & 1597 & 1597 & 1597 & 1597 \\
\hline Unit & decimal & ratio & In & ratio & In & ratio \\
\hline Expected coefficient & Dependent & $(+)$ & $(-)$ & $(+)$ & $(+)$ & $(+)$ \\
\hline
\end{tabular}

Results obtained via Stata ${ }^{\circledR}$ software. 
As it can be seen in Figure 4.1, the average abnormal return was $4.89 \%$ in the period. Nevertheless, it could be observed high variability of abnormal returns, varying from a $554.67 \%$ maximum positive return to a $112.75 \%$ negative return.

In addition, Figure 4.1 also provides that, on average, $0.1 \%$ of investments of the total assets were seen in R\&D activities. The average current liquidity index shows that for each $\mathrm{R} \$ 1.00$ (BRL) short-term liability, the company has $\mathrm{R} \$ 1.8384$ for debt coverage. Regarding the indebtedness variable, for each R $\$ 1.00$ of equity, the firm uses R $\$ 4.92$ of third-party funds. Finally, profitability demonstrates high variability, which ranges from a 20.13 maximum positive return to a 10.98 minimum negative return.

Figures 4.2 and 4.3 show the results from panel data regressions. We estimated each model according to the results of Chow, Breusch-Pagan and Hausman tests. Thus, the results indicate that the fixed effect model is suitable.

In addition, regarding the variance inflation factor (VIF) test for the assumption of multicollinearity in the models, it can be observed the absence of multicollinearity. About the assumption of homoscedasticity, BreuschPagan/Cook-Weisberg test shows that it is rejected the homoscedasticity hypothesis for all estimated models, that is why the models presented in figures 4.2 and 4.3 were estimated with the matrix of variance-covariance robust.

Note that for robustness purposes, we also estimate the models with additional control variables. That is, control variables for years, sectors, periods of crisis - assuming 1 for 2008, 2009, 2014, 2015 and 2016, and 0 for the remaining years of our sample, and also a control variable for macroeconomic effects using Brazilian GDP growth.

Figures 4.2 and 4.3 demonstrate a negative relationship between the abnormal return and $\mathrm{R} \& \mathrm{D}$ expenses. This evidence does not corroborate with our hypothesis and, consequently, does not support the Resource-Based Theory, known as RBT (Barney, 1991). Therefore, it cannot be stated that the Brazilian firms which invest in R\&D offer their investors a greater return differential (spread) than their counterparts. The negative relationship indicates that an increase in $\mathrm{R} \& \mathrm{D}$ spending reduces the firm's abnormal return. The abnormal return can fall whether the company's actual return is dropped or the expected return of the company by CAPM increase. 


\section{(Figure 4.2)}

PANEL DATA REGRESSIONS: MODELS FROM 1 TO 3

\begin{tabular}{|c|c|c|c|}
\hline \multirow{2}{*}{$\begin{array}{l}\text { Dependent variable } \\
\text { Independent variables }\end{array}$} & \multicolumn{3}{|c|}{ Abnormal return } \\
\hline & t Stat. & t Stat. & t Stat. \\
\hline INOV & $-5.21^{\star \star \star}$ & $-5.21^{\star \star \star}$ & $-4.07^{\star \star \star}$ \\
\hline Size & $-4.81^{\star \star \star}$ & $-4.81^{\star \star \star}$ & $-2.9^{\star \star \star}$ \\
\hline Liquidity & 1.12 & 1.12 & 0.02 \\
\hline Indebtedness & 0.01 & 0.01 & 0.24 \\
\hline Profitability & $4.71^{\star \star \star}$ & $4.71^{\star \star \star}$ & $5.38^{\star \star \star}$ \\
\hline \multicolumn{4}{|l|}{ GDP Brazil } \\
\hline Constant & $4.76^{\star \star \star}$ & $4.76^{\star \star \star}$ & $3.05^{\star \star \star}$ \\
\hline Model & 1 & 2 & 3 \\
\hline Estimation & $\begin{array}{l}\text { Robust fixed } \\
\text { effects }\end{array}$ & $\begin{array}{l}\text { Robust fixed } \\
\text { effects }\end{array}$ & $\begin{array}{l}\text { Robust fixed } \\
\text { effects }\end{array}$ \\
\hline Control for crisis & No & No & No \\
\hline Control for years & No & No & Yes \\
\hline Control for sectors & No & Yes & No \\
\hline N & \multicolumn{3}{|c|}{1597} \\
\hline Prob $>F$ & 0.000 & 0.000 & 0.000 \\
\hline$R^{2}$ & 0.14 & 0.14 & 0.4 \\
\hline Chow test & $1.14^{\star \star \star}$ & $1.44^{\star \star \star}$ & $1.20 \star \star$ \\
\hline Breusch-Pagan test & $15.18^{\star \star \star}$ & $21.44^{\star \star \star}$ & $1.78^{\star}$ \\
\hline Hausman test & $134.80^{\star \star \star}$ & $135.3^{\star \star \star}$ & $62.12^{\star \star \star}$ \\
\hline $\begin{array}{l}\text { Breusch-Pagan/Cook-Weisberg } \\
\text { test for heteroskedasticity } \\
\text { (F-statistic) }\end{array}$ & $3.01^{*}$ & $14.22^{\star \star \star}$ & $876.33^{\star \star \star}$ \\
\hline Multicolinearity test (Mean VIF) & 1.18 & 2.71 & 1.6 \\
\hline
\end{tabular}

Results obtained via Stata ${ }^{\circledR}$ software. Significance level: ${ }^{*} 10 \%,{ }^{\star \star \star} 5 \%,{ }^{\star \star \star} 1 \%$.

Source: Elaborated by the authors. 


\section{(Figure 4.3)}

PANEL DATA REGRESSIONS: MODELS FROM 4 TO 6

\begin{tabular}{|c|c|c|c|}
\hline Dependent variable & & Abnormal return & \\
\hline Independent variables & t Stat. & t Stat. & t Stat. \\
\hline INOV & $-4.97^{\star \star \star}$ & $-4.07^{\star \star \star}$ & $-3.61^{\star \star \star}$ \\
\hline Size & $-4.58^{\star \star \star}$ & $-2.9^{\star \star \star}$ & 0,00 \\
\hline Liquidity & 0.06 & 0.49 & 1.03 \\
\hline Indebtedness & -0.08 & 0.24 & 0.02 \\
\hline Profitability & $5.81^{\star \star \star}$ & $5.38^{\star \star \star}$ & $8.9^{\star \star \star}$ \\
\hline GDP Brazil & & & $5.82^{\star \star \star}$ \\
\hline Constant & $4.44^{\star \star \star}$ & $3.05^{\star \star \star}$ & $-2.81^{\star \star \star}$ \\
\hline Model & 4 & 5 & 6 \\
\hline Estimation & $\begin{array}{l}\text { Robust fixed } \\
\text { effects }\end{array}$ & $\begin{array}{l}\text { Robust fixed } \\
\text { effects }\end{array}$ & $\begin{array}{l}\text { Robust fixed } \\
\text { effects }\end{array}$ \\
\hline Control for crisis & Yes & No & No \\
\hline Control for years & No & Yes & Yes \\
\hline Control for sectors & No & Yes & Yes \\
\hline N & & 1597 & \\
\hline Prob $>F$ & 0.000 & 0.000 & 0.000 \\
\hline$R^{2}$ & 0.22 & 0.40 & 0.37 \\
\hline Chow test & $1.63^{\star \star \star}$ & $1.20^{\star *}$ & $1.20 * \star$ \\
\hline Breusch-Pagan test & $10.98^{\star \star \star}$ & $6.12^{\star \star \star}$ & $6.12^{\star \star \star}$ \\
\hline Hausman test & $172^{\star \star \star}$ & $58.79^{\star \star \star}$ & $58.79^{\star \star \star \star}$ \\
\hline $\begin{array}{l}\text { Breusch-Pagan/Cook-Weisberg } \\
\text { test for heteroskedasticity } \\
\text { (F-statistic) }\end{array}$ & $207.74^{\star \star \star}$ & $878.81^{\star \star \star}$ & $878.81^{\star \star \star}$ \\
\hline Multicolinearity test (mean VIF) & 1.15 & 2.38 & 2.2 \\
\hline
\end{tabular}

Results obtained via Stata ${ }^{\circledR}$ software. Significance level: * $10 \%$, ** $5 \%$, *** $1 \%$.

Source: Elaborated by the authors. 
Considering that the period was affected by turbulences in the Brazilian economic scenario, our results are robust to additional controls, including dummy variables from crisis periods and macroeconomic effects using Brazilian GDP growth. When there is an increase in the economy basic interest rates, the fixed income investments became more attractive to conservative investors and even to the most aggressive ones who, interested in assuring their investment yield, migrate from variable returns to more conservative investment funds (Martello, 2016; Wolf, 2017). Since one of the main factors which impact the share price, a product of the variable return with more emphasis in the Brazilian financial market, relate to the law of supply and demand, the drop in demand for shares contributes to the devaluation of their prices. Consequently, the actual return $\left(R_{E}\right)$ of the shares of the firms tends to be lower (Lintner, 1965; Sharpe, 1964).

In addition, in Brazil, government incentives to private companies for innovation are concentrated in few and large organizations, especially in manufacturing and electric power industries. Consequently, investments in R\&D would be discouraged in the Brazilian economic environment, which makes it uninteresting to invest in innovative activities (Espíndola, Santos, \& Vasconcelos, 2018).

Furthermore, investors could prefer and reward shares of companies that would bring them higher returns in the short term, especially in the Brazilian stock market that is not developed yet. It could reduce the demand for shares of companies with these characteristics, because there is a gap between R\&D expenses and the real impact on a firm, which could be perceived just in longer periods (Lev, 2001; Gupta, 2011; Upton, 2001; Ambler, 2003; Camargo et al., 2016). Consequently, it would lead to a reduction in the prices of their shares.

The results also determined that firm' characteristics influence the abnormal return, such as profitability and firm size. The positive coefficient from profitability signals that the greater operational performance, the greater its abnormal return, according to expected by literature.

A significant and negative relationship between size and the Abnormal Return was observed. A reasonable justification for such behavior is that firms with bigger size, including those with a greater number of intangible assets and, consequently, more volatile performance, have more coverage of financial analysts who aim the anticipation of the company future results by obtaining its share pricing reports, which are a complement to its balance sheets and, afterward, the market will absorb such information to adjust the asset price (Barth et al., 2001; Frankel, Kothari, \& Weber, 2006; Givoly, Hayn, \& Lehavy, 2009; Jin \& Myers, 2006). 
Another aspect to the negative and statistically significant relationship between the size and abnormal return is in the risk and return theory that advocates the greater the risk, the greater the expected return. Thus, shares of smaller firms (small caps) are, in thesis, riskier than big firms' shares (blue chips), and, therefore, they must offer a greater return to the shareholders. Thus, the negative coefficient sign for the Size control variable is in accordance with the theory (Markowitz, 1952).

Finally, additional analyses were carried out aiming to check the consistency of our previous evidences. According to Figure 4.4, the Serial Autocorrelation Test rejects the null hypothesis that there is no serial autocorrelation nor correlation in the residuals of the estimated regression, which constitutes an endogeneity problem.

\section{(Figure 4.4)}

SERIAL AUTOCORRELATION TEST

\begin{tabular}{|c|c|c|c|c|c|c|}
\hline Models & 1 & 2 & 3 & 4 & 5 & 6 \\
\hline \multicolumn{7}{|c|}{ Autocorrelation Wooldridge Test for panel data } \\
\hline F statistic & $87.926^{\star \star \star}$ & $87.926^{\star \star \star}$ & $37.145^{\text {*** }}$ & $63.312^{\star \star \star}$ & $37.145^{\star \star \star}$ & $37.145^{\text {*** }}$ \\
\hline
\end{tabular}

Consequently, we applied Arellano and Bond (1991) estimation method, suitable for the situation in which it is not possible to assure the endogeneity of the explanatory variables of the model, using the abnormal return dependent variable $(R A)$ lagged in a period.

The results obtained according to the Arellano-Bond estimate are comparable to those estimated before in the fixed-effect model, regarding the signal and the significance level, indicating that when there was bias in the coefficients, they were not relevant. Thus, the consistency of the results is assured.

For robustness purposes, the models presented in figures 4.2 and 4.3 were estimated only for companies that have R\&D expenditures, as shown in figures 4.6 and 4.7 . 


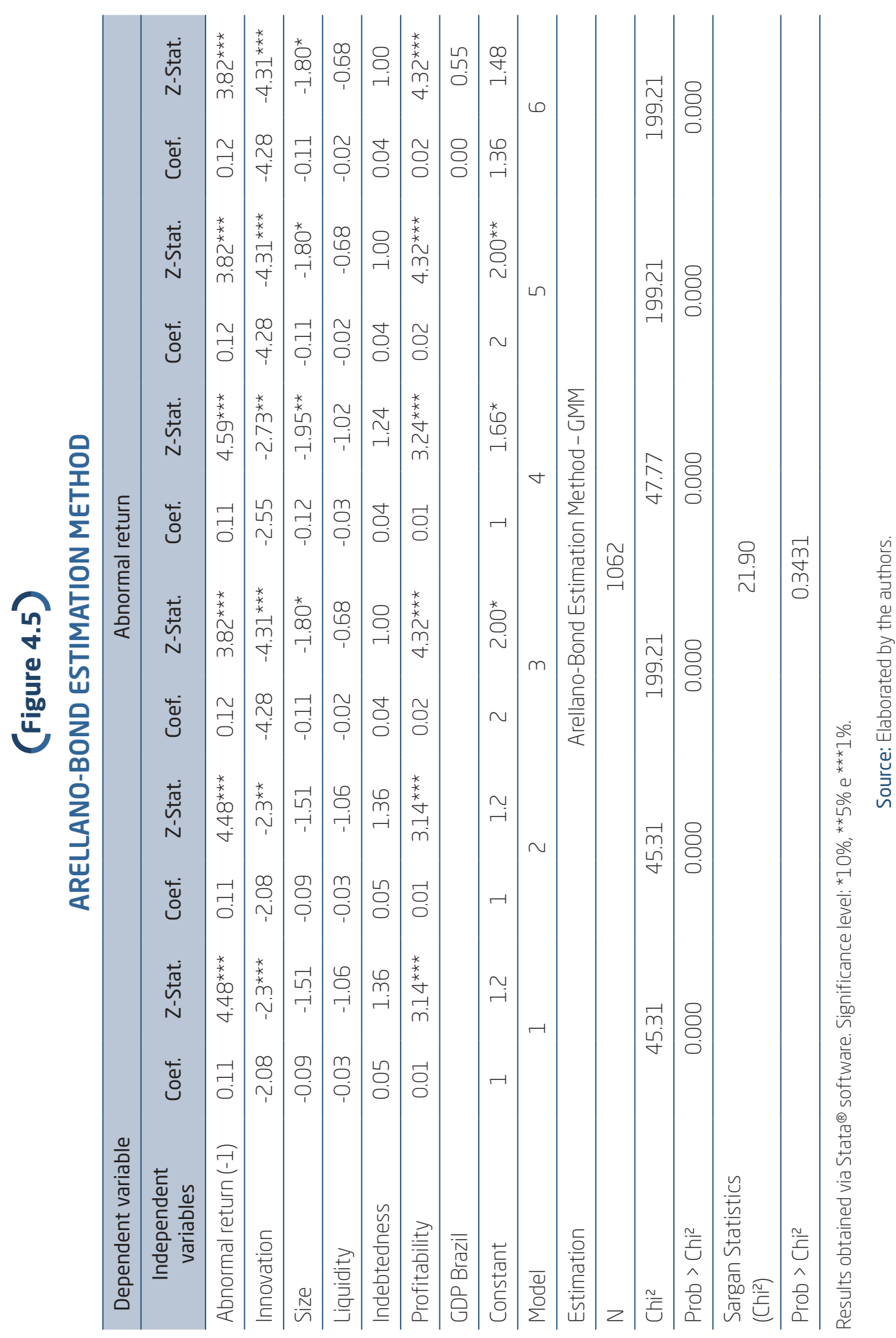




\section{(Figure 4.6)}

PANEL DATA REGRESSION ONLY WITH COMPANIES INVESTING IN R\&D: MODELS FROM 1 TO 3

\begin{tabular}{|c|c|c|c|c|c|c|}
\hline \multirow{2}{*}{$\begin{array}{c}\text { Dependent variable } \\
\text { Independent variables }\end{array}$} & \multicolumn{6}{|c|}{ Abnormal return } \\
\hline & Coef. & t Stat. & Coef. & t Stat. & Coef. & t Stat. \\
\hline INOV & -0.41 & -0.37 & -0.86 & -1.28 & -2.51 & $-2.12^{\star *}$ \\
\hline Size & 0,00 & -0.21 & -0.03 & -1.03 & -0.11 & $-1.87^{\star}$ \\
\hline Liquidity & -0.08 & $-2.01^{\star \star}$ & -0.1 & $-2.44^{\star \star}$ & -0.04 & -0.42 \\
\hline Indebtedness & 0.01 & 0.22 & 0.03 & 0.38 & 0.18 & $1.91^{\star}$ \\
\hline Profitability & 0.02 & $3.82^{\star \star \star}$ & 0.02 & $3.3^{\star \star \star}$ & 0.02 & $2.07^{\star \star}$ \\
\hline \multicolumn{7}{|l|}{ GDP Brazil } \\
\hline Constant & 0.04 & 0.1 & 0.23 & 0.47 & 1.01 & 0.93 \\
\hline Model & \multicolumn{2}{|c|}{1} & \multicolumn{2}{|c|}{2} & \multicolumn{2}{|c|}{3} \\
\hline Estimation & \multicolumn{2}{|c|}{ POLS } & \multicolumn{2}{|c|}{ Robust POLS } & \multicolumn{2}{|c|}{$\begin{array}{l}\text { Robust fixed } \\
\text { effects }\end{array}$} \\
\hline Control for Crisis & \multicolumn{2}{|c|}{ No } & \multicolumn{2}{|c|}{ No } & \multicolumn{2}{|c|}{ No } \\
\hline Control for Years & \multicolumn{2}{|c|}{ No } & \multicolumn{2}{|c|}{ No } & \multicolumn{2}{|c|}{ Yes } \\
\hline Control for Sectors & \multicolumn{2}{|c|}{ No } & \multicolumn{2}{|c|}{ Yes } & \multicolumn{2}{|c|}{ No } \\
\hline N & \multicolumn{6}{|c|}{207} \\
\hline Prob > F & \multicolumn{2}{|c|}{0.000} & \multicolumn{2}{|c|}{0.000} & \multicolumn{2}{|c|}{0.000} \\
\hline$R^{2}$ & \multicolumn{2}{|c|}{0.11} & \multicolumn{2}{|c|}{0.14} & \multicolumn{2}{|c|}{0.26} \\
\hline Chow test & \multicolumn{2}{|c|}{1.37} & \multicolumn{2}{|c|}{1.37} & \multicolumn{2}{|c|}{$1.40^{\star}$} \\
\hline Breusch-Pagan test & \multicolumn{2}{|c|}{0.00} & \multicolumn{2}{|c|}{0.00} & \multicolumn{2}{|c|}{0.00} \\
\hline Hausman test & \multicolumn{2}{|c|}{8.81} & \multicolumn{2}{|c|}{7.66} & \multicolumn{2}{|c|}{16.32} \\
\hline $\begin{array}{l}\text { Multicolinearity test (mean } \\
\text { VIF) }\end{array}$ & \multicolumn{2}{|c|}{1.38} & & 58 & & \\
\hline
\end{tabular}

Results obtained via Stata ${ }^{\circledR}$ software. Significance level: * $10 \%$, ${ }^{\star \star} 5 \%$ e ${ }^{\star \star \star} 1 \%$.

Source: Elaborated by the authors. 


\section{(Figure 4.7)}

PANEL DATA REGRESSION ONLY WITH COMPANIES INVESTING IN R\&D: MODELS FROM 4 TO 6

\begin{tabular}{|c|c|c|c|c|c|c|}
\hline \multirow{2}{*}{$\begin{array}{c}\text { Dependent variable } \\
\text { Independent variables }\end{array}$} & \multicolumn{6}{|c|}{ Abnormal return } \\
\hline & Coef. & t Stat. & Coef. & t Stat. & Coef. & t Stat. \\
\hline INOV & -0.5 & -0.81 & -2.51 & $-2.12^{\star \star}$ & -1.45 & $-1.77^{\star}$ \\
\hline Size & 0,00 & -0.25 & -0.11 & $-1.87^{\star \star}$ & -0.02 & -0.93 \\
\hline Liquidity & -0.08 & $-2.01^{\star \star}$ & -0.04 & -0.42 & -0.09 & $-2.39 * *$ \\
\hline Indebtedness & 0,00 & -0.03 & 0.18 & $1.91^{\star}$ & 0.03 & 0.44 \\
\hline Profitability & 0.02 & 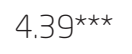 & 0.02 & $2.07^{\star \star}$ & 0.02 & $3.32^{\star \star \star}$ \\
\hline \multicolumn{5}{|l|}{ GDP Brazil } & 0.01 & 1.02 \\
\hline Constant & 0.05 & 0.1 & 1.01 & 0.93 & 0.36 & 0.77 \\
\hline Model & \multicolumn{2}{|c|}{4} & \multicolumn{2}{|c|}{5} & \multicolumn{2}{|c|}{6} \\
\hline Estimation & \multicolumn{2}{|c|}{ Robust POLS } & \multicolumn{2}{|c|}{ Robust fixed effects } & \multicolumn{2}{|c|}{ Robust POLS } \\
\hline Control for crisis & \multicolumn{2}{|c|}{ Yes } & \multicolumn{2}{|c|}{ No } & \multicolumn{2}{|c|}{ No } \\
\hline Control for years & \multicolumn{2}{|c|}{ No } & \multicolumn{2}{|c|}{ Yes } & \multicolumn{2}{|c|}{ Yes } \\
\hline Control for sectors & \multicolumn{2}{|c|}{ No } & \multicolumn{2}{|c|}{ Yes } & \multicolumn{2}{|c|}{ Yes } \\
\hline N & \multicolumn{6}{|c|}{207} \\
\hline Prob $>F$ & \multicolumn{2}{|c|}{0.000} & \multicolumn{2}{|c|}{0.000} & \multicolumn{2}{|c|}{0.000} \\
\hline$R^{2}$ & \multicolumn{2}{|c|}{0.12} & \multicolumn{2}{|c|}{0.26} & \multicolumn{2}{|c|}{0.31} \\
\hline Chow test & \multicolumn{2}{|c|}{1.31} & \multicolumn{2}{|c|}{$1.40^{\star}$} & \multicolumn{2}{|c|}{$1.40^{\star}$} \\
\hline Breusch-Pagan test & \multicolumn{2}{|c|}{0.00} & \multicolumn{2}{|c|}{0.00} & \multicolumn{2}{|c|}{0.00} \\
\hline Hausman test & \multicolumn{2}{|c|}{7.56} & \multicolumn{2}{|c|}{16.11} & \multicolumn{2}{|c|}{0.19} \\
\hline $\begin{array}{l}\text { Multicolinearity test (mean } \\
\text { VIF) }\end{array}$ & \multicolumn{2}{|c|}{1.33} & & & & .92 \\
\hline
\end{tabular}

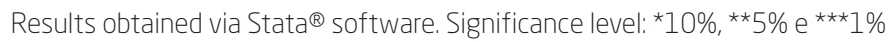

Source: Elaborated by the authors.

We also estimated by the Arellano and Bond (1991) estimation method, considering only firms that invest in R\&D, as Figure 4.8. 


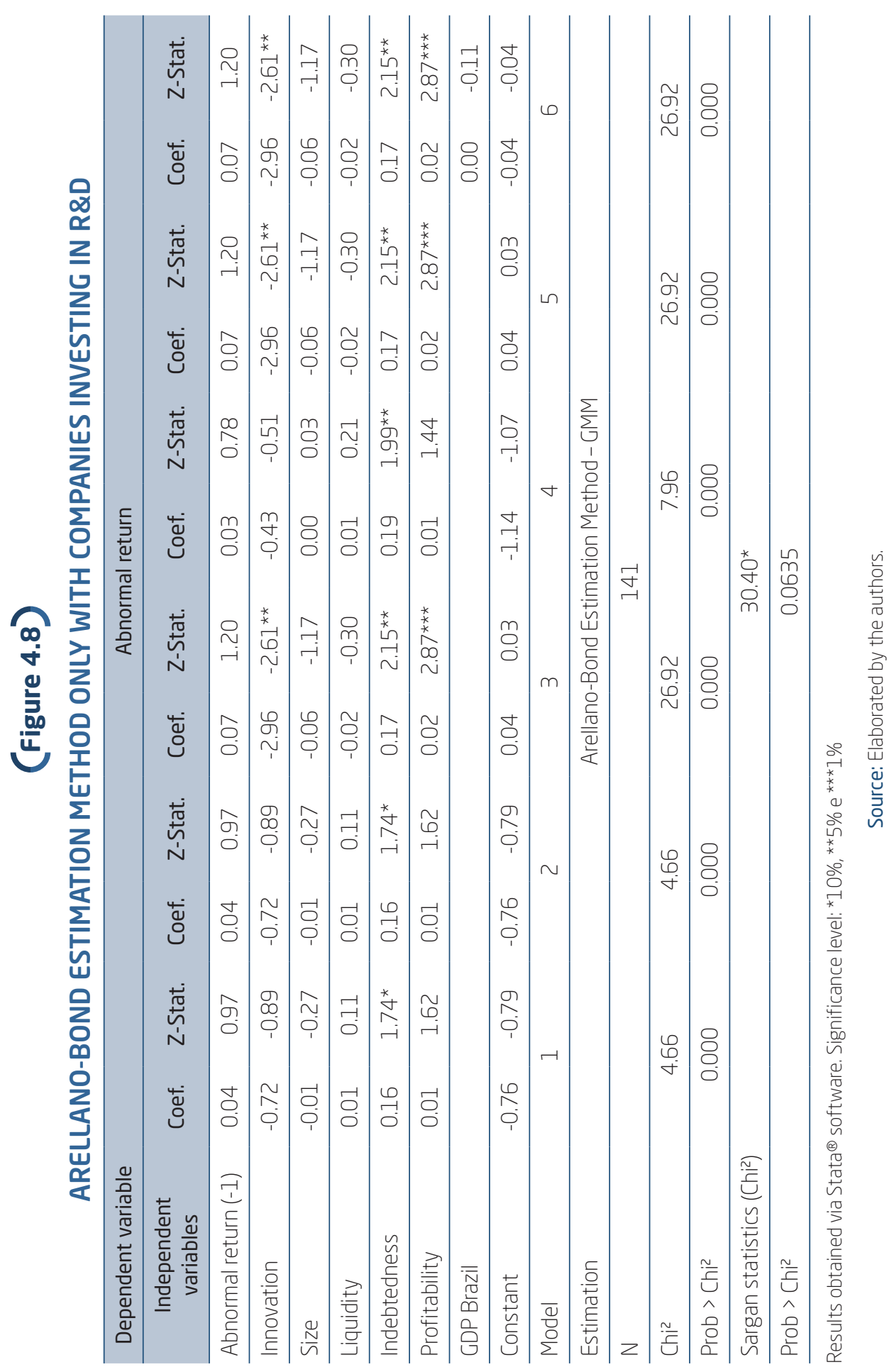


As it could be seen in figures $4.6,4.7$, and 4.8 , the results remain consistent with our previous estimations from panel data regressions for all the sample, indicating a negative relationship between $R \& D$ expenses and abnormal returns in Brazilian public firms.

\section{CONCLUDING REMARKS}

We analyzed the relationship between abnormal return (RA), measured by the difference between the actual return and the expected return, and innovation, measured by the ratio between $R \& D$ expenses and total assets.

For this purpose, we collected data from a wide sample of non-financial public firms (B3) in Brazil, from 2009 to 2016. From panel data regressions, our findings demonstrated a negative and statistically significant relationship between R\&D expenses and abnormal return (RA) in the firms analyzed. That is, an increase in R\&D expenses, on average, reduces the firm's abnormal returns. The abnormal return can fall whether the company's actual return is dropped or the expected return of the company by CAPM increase.

In addition, our findings also demonstrated that some firm variables influence the abnormal return, such as firm size and profitability. There is a negative relationship between the firm size and the abnormal return. In relation to profitability, the results showed that a greater profitability increases the abnormal return.

Considering that our research period comprises an economic and political crisis scenario, additional tests with macroeconomic controls corroborate with our previous estimations, demonstrating a negative relationship between innovation and abnormal return. This economic turbulence could lead to the drop in share demand and devaluation of their prices. That is, the actual return tends to be, in fact, lower, decreasing the abnormal return (Lintner, 1965; Sharpe, 1964).

Another aspect that could influence this relationship is the fact that Brazilian government incentives to private companies for innovation are concentrated in few and large organizations, and it could discourage innovative activities (Espíndola et al., 2018). Furthermore, investors could prefer and reward shares of companies that would bring them higher returns in the short term, reducing the demand for shares of companies with innovative characteristics, because it takes more time for the investments made to be recovered (Lev, 2001; Gupta, 2011; Upton, 2001; Ambler, 2003; Camargo et al., 2016). 
Furthermore, our findings suggest that an investment from current $\mathrm{R} \& \mathrm{D}$ expenses leads to a lower current abnormal return. Consequently, there is a lack between current $R \& D$ expenses and the abnormal return. It could be related to the fact that $R \& D$ expenses will become in fact innovations, just in longer periods. It raises the need for future studies so that we suggest that future studies could verify the effects of R\&D expenses on future stock returns and future abnormal stock returns.

\section{A RELAÇÃO ENTRE AS DESPESAS COM P\&D E O RETORNO ANORMAL DAS EMPRESAS BRASILEIRAS}

\section{RESUMO}

Objetivo: O estudo tem como objetivo analisar a relação entre o retorno anormal e as despesas com P\&D em empresas listadas brasileiras.

Originalidade/valor: Os determinantes do retorno anormal das empresas fornecem informações relevantes para a tomada de decisões dos investidores. Nesse contexto, foi analisado se a inovação, mensurada pelas despesas com $\mathrm{P} \& \mathrm{D}$, pode ser um fator-chave para o retorno anormal das empresas brasileiras.

Design/metodologia/abordagem: Foram analisadas as empresas brasileiras de capital aberto, de 2009 a 2016, em uma amostra composta por 1.597 observações, por meio de análise de regressão com dados em painel. As informações sobre despesas com P\&D foram coletadas nas Notas Explicativas. Se a empresa mencionou apenas as despesas com P\&D e não divulgou o valor gasto na Demonstração do Resultado do Exercício, considerou-se que a empresa não investiu no período e o valor zero foi atribuído. Destaca-se que somente 44 empresas da amostra mencionaram as despesas com P\&D em suas Notas Explicativas e/ou declararam que investiram em $\mathrm{P} \& \mathrm{D}$, sinalizando a importância de melhores práticas de divulgação desses investimentos.

Resultados: Os resultados evidenciam uma relação negativa e estatisticamente significativa entre a inovação e o retorno anormal. Ou seja, um investimento corrente por meio de despesas com P\&D leva a um menor retorno anormal corrente. Isso poderia estar ligado ao fato de que as despesas com $\mathrm{P} \& \mathrm{D}$ tendem a produzir retornos apenas em períodos 
mais longos, exigindo um tempo maior para recuperar esses investimentos, devido às características complexas relacionadas à mensuração contábil das despesas com P\&D. Consequentemente, o retorno anormal só poderia ser percebido em períodos subsequentes.

\section{PALAVRAS-CHAVE}

Retorno anormal. Ativos intangíveis. Inovação. Despesas com P\&D. Mercado financeiro brasileiro.

\section{REFERENCES}

Aboody, D., \& Lev, B. (2000). Information asymmetry, R\&D, and insider gains. The Journal of Finance, 55(6), 2747-2766. doi:10.1111/0022-1082. 00305

Ambler, T. (2003). Marketing and the bottom line: The marketing metrics to pump up cash flow. London: Pearson Education.

Araújo, E., Fajardo, J., \& Tavani, L. C. D. (2006). CAPM usando uma carteira sintética do PIB brasileiro. Estudos Econômicos, 36 (3), 465-505. doi:10.1590/ S0101-41612006000300003

Araújo, E. A. T., Oliveira, V. C., \& Silva, W. A. C. (2012). CAPM em estudos brasileiros: Uma análise da pesquisa. Revista de Contabilidade e Organizações, 6(15), 95-122. doi:10.11606/rco.v6i15.52659

Arellano, M., \& Bond, S. (1991). Some tests of specification for panel data: Monte Carlo evidence and an application to employment equations. The Review of Economic Studies, 58(2), 277-297. doi:10.2307/2297968

Argolo, E. F. B., Leal, R. P. C., \& Almeida, V. de S. (2012, May). O modelo de Fama e French é aplicável ao Brasil? Rio de Janeiro: UFRJ/Coppead.

Azevedo, F. N., \& Gutierrez, C. E. C. (2009). A relação dos gastos com P\&D na taxa de crescimento de longo prazo das empresas listadas na NYSE. Congresso IAAER ANPCONT, São Paulo, SP, Brasil, 3.

Barney, J. (1991). Firm resources and sustained competitive advantage. Journal of Management, 17(1), 99-120. doi:10.1177/014920639101700108

Barros, L. A. B. de C., Silveira, A. D. M. da, \& Famá, R. (2003). Estrutura de governança e valor das companhias abertas brasileiras. Revista de Administração de Empresas, 43 (3), 50-64. doi:10.1177/014920639101700108 
Barth, M. E., Kasznik, R., \& McNichols, M. F. (2001). Analyst coverage and intangible assets. Journal of Accounting Research, 39(1), 1-34. doi:10.1111/ 1475-679X.00001

Beattie, V., McInnes, B., \& Fearnley, S. (2004). A methodology for analysing and evaluating narratives in annual reports: A comprehensive descriptive profile and metrics for disclosure quality attributes. Accounting Forum, 28, 205-236. doi:10.1016/j.accfor.2004.07.001

Benetti, C., Decourt, R. F., \& Terra, P. R. S. (2008). The practice of corporate finance in Brazil and in the USA: Comparative survey evidence. Encontro Brasileiro de Finanças, Rio de Janeiro, RJ, Brasil, 7.

Besanko, D., Dranove, D., Shanley, M., \& Schaefer, S. (2009). Economics of strategy. New York: John Wiley \& Sons.

Blume, M. E., \& Friend, I. (1973). A new look at the capital asset pricing model. The Journal of Finance, 28(1), 19-34. Retrieved from https://www. jstor.org/stable/2978165

Brito, E. P. Z., Brito, L. A. L., \& Morganti, F. (2009). Inovação e o desempenho empresarial: Lucro ou crescimento? RAE - eletrônica, 8(1), 1-24. Retrieved from https://rae.fgv.br/sites/rae.fgv.br/files/artigos/10.1590_S167656482009000100007.pdf

Camargo, T. F., Zanin, A., Diel, F. J., \& Bianchet, T. D. S. A. (2016). Influência da P\&D no desempenho de empresas: Análise do bloco econômico G-20. Anais do Congresso Brasileiro de Custos, Vitória, ES, Brasil, 25.

Chan, L. K., Lakonishok, J., \& Sougiannis, T. (2001). The stock market valuation of research and development expenditures. The Journal of Finance, 56(6), 2431-2456. doi:10.1111/0022-1082.00411

Chan, S. H., Martin, J. D., \& Kensinger, J. W. (1990). Corporate research and development expenditures and share value. Journal of Financial Economics, 26(2), 255-276. doi:10.1016/0304-405X(90)90005-K

Chander, S., \& Mehra, V. (2011). A study on intangible assets disclosure: An evidence from Indian firms. Intangible Capital, 7(1), 1-30. doi:10.3926/ic.198

Chaney, P. K., \& Devinney, T. M. (1992). New product innovations and stock price performance. Journal of Business Finance \& Accounting, 19(5), 677-695. doi:10.1111/j.1468-5957.1992.tb00651.x

Cho, H. J., \& Pucik, V. (2005). Relationship between innovativeness, quality, growth, profitability, and market value. Strategic Management Journal, 26(6), 555-575. doi:10.1002/smj.461

Comitê de Pronunciamentos Contábeis (2010). Pronunciamento Técnico CPC 04 (R1): Ativo intangível. Recuperado de https://bit.ly/2vlQJbI 
Daniel, K., \& Titman, S. (2006). Market reactions to tangible and intangible information. The Journal of Finance, 61 (4), 1605-1643. doi:10.1111/j.15406261.2006.00884.x

Decker, F., Ensslin, S. R., Reina, D. R. M., \& Reina, D. (2013). A relação entre os ativos intangíveis e a rentabilidade das ações: Um estudo com empresas listadas no índice Bovespa. Reuna, 18(4), 75-92.

Donnelly, R. (2014). The book-to-market ratio, optimism and valuation. Journal of Behavioral and Experimental Finance, 4, 14-24. doi:10.1016/j.jbef. 2014.10.002

Dosi, G. (1988). Sources, procedures, and microeconomic effects of innovation. Journal of Economic Literature, 26(3),1120-1171. Recuperado de https:// www.jstor.org/stable/2726526

Espíndola, A. A., Santos, J. G. C., \& Vasconcelos, A. C. (2018) Relevância informacional atribuída ao disclosure de gastos com P\&D no mercado de capitais brasileiro. Contextus - Revista Contemporânea de Economia e Gestão, 115-140. doi:10.19094/contextus.v0i0.33312

Fama, E. F., \& French, K. R. (1993). Common risk factors in the returns on stocks and bonds. Journal of Financial Economics, 33(1), 3-56. doi:10.1016/ 0304-405X(93)90023-5

Fellet, B. G. (2016). Avaliação de modelos de precificação de ativos no mercado acionário brasileiro (Dissertacão de mestrado, Universidade de Brasília, Brasília, DF, Brasil). doi:10.26512/2016.02.D.20125

Figari, A. K. P., Tortoli, J. P., Silva, W. A. M. da, \& Ambrozini, M. A. (2017). Relação entre gastos com pesquisa e índice book-to-market no Brasil. Contabilometria, 4(2), 1-17. Recuperado de https://bit.ly/2Vk4Z3p

Frankel, R., Kothari, S. P., \& Weber, J. (2006). Determinants of the informativeness of analyst research. Journal of Accounting and Economics, 41(1-2), 29-54. doi:10.1016/j.jacceco.2005.10.004

Givoly, D., Hayn, C., \& Lehavy, R. (2009). The quality of analysts' cash flow forecasts. The Accounting Review, 84(6), 1877-1911. doi:10.2308/accr.2009. 84.6.1877

Gopalakrishnan, S. (2000). Unraveling the links between dimensions of innovation and organizational performance. The Journal of High Technology Management Research, 11(1), 137-153. doi:10.1016/S1047-8310(00)00024-9

Graham, J. R., \& Harvey, C. R. (2001). The theory and practice of corporate finance: Evidence from the field. Journal of Financial Economics, 60(2-3), 187-243. doi:10.1016/S0304-405X(01)00044-7 
Gupta, N. (2011). Reflexo dos gastos em PED e inovação no valor de mercado das empresas químicas brasileiras (Dissertação de mestrado, Fundação Getulio Vargas, São Paulo, SP, Brasil).

Hall, B. H. (1986). The relationship between firm size and firm growth in the US manufacturing sector. Journal of Industrial Economics, 35(4), 583-600. Recuperado de https://www.jstor.org/stable/2098589

Hall, B. H. (2000). Innovation and market value. In R. Barrell, G. Manson, \& M. O'Mahony (Ed.). Productivity, innovation and economic performance. Cambridge: Cambridge University Press.

Hendriksen, E. S., \& Van Breda, M. F. (1999). Teoria da contabilidade. São Paulo: Atlas.

Hirschey, M., \& Weygandt, J. J. (1985). Amortization policy for advertising and research and development expenditures. Journal of Accounting Research, 23(1), 326-335. Recuperado de https://www.jstor.org/stable/2490921

Honorato, H. G. (2008). A influência dos ativos intangíveis na análise de risco de crédito de empresas de base tecnológica (Dissertação de mestrado, Fundação Getulio Vargas, São Paulo, SP, Brasil).

Jegadeesh, N., \& Titman, S. (1993). Returns to buying winners and selling losers: Implications for stock market efficiency. The Journal of Finance, 48(1), 65-91. doi:10.1111/j.1540-6261.1993.tb04702.x

Jin, L., \& Myers, S. C. (2006). R2 around the world: New theory and new tests. Journal of Financial Economics, 79(2), 257-292. doi:10.1016/j.jfineco. 2004.11.003

Kaplan, R. S., \& Norton, D. P. (2000). Organização orientada para a estratégia: Como as empresas que adotam o balanced scorecard prosperam no novo ambiente de negócios. Rio de Janeiro: Elsevier.

Kayo, E. K. (2002). A estrutura de capital e o risco das empresas tangível e intangível-intensivas: Uma contribuição ao estudo da valoração de empresas (Tese de doutorado, Universidade de São Paulo, São Paulo, SP, Brasil). doi:10.11606/ T.12.2002.tde-05032003-194338

Keck, T., Levengood, E., \& Longfield, A. L. (1998). Using discounted cash flow analysis in an international setting: A survey of issues in modeling the cost of capital. Journal of Applied Corporate Finance, 11 (3), 82-99. doi:10. 1111/j.1745-6622.1998.tb00505.x

Klomp, L., \& Van Leeuwen, G. (2001). Linking innovation and firm performance: A new approach. International Journal of the Economics of Business, 8(3), 343-364. doi:10.1080/13571510110079612 
Kothari, S. P., Laguerre, T. E., \& Leone, A. J. (1998). Capitalization versus expensing: Evidence on the uncertainty of future earnings from current investments in PP\&E versus R\&D [Working Paper FR 99-02]. Simon School of Business, Rochester, NY.

Lazzarotti, V., Manzini, R., \& Mari, L. (2011). A model for R\&D performance measurement. International Journal of Production Economics, 134(1), 212-223. doi:10.1016/j.ijpe.2011.06.018

Lee, J., \& Shim, E. (1995). Moderating effects of R\&D on corporate growth in US and Japanese hi-tech industries: An empirical study. The Journal of High Technology Management Research, 6(2), 179-191. doi:10.1016/10478310(95)90013-6

Lev, B. (2001). Intangibles: Management, measurement, and reporting. Washington, DC: The Brooking Institution.

Lintner, J. (1965). Security prices, risk, and maximal gains from diversification. The Journal of Finance, 20(4), 587-615. doi:10.1111/j.1540-6261.1965. tb02930

Mansfield, E. (1962). Entry, Gibrat's law, innovation, and the growth of firms. The American Economic Review, 52 (5), 1023-1051. Recuperado de https://bit.ly/2ISsgTq

Markowitz, H. (1952). Portfolio selection. The Journal of Finance, 7(1), 77-91. doi:10.1111/j.1540-6261.1952.tb01525.x

Martello, A. (2016). Pela $7^{\circ}$ vez seguida, BC mantém juro em 14,25\%, maior taxa em 10 anos. Globo.com. Recuperado de https://glo.bo/1WFxhQ1

Matos, P. R. F., \& Rocha, J. A. T de. (2009). Ações e fundos de investimento em ações: Fatores de risco comuns? Brazilian Business Review, 6(1), 22-43. Recuperado de https://bit.ly/2Vvaht3

Menezes, N., Filho, Komatsu, B., Lucchesi, A., \& Ferrario, M. (2014). Políticas de inovação no Brasil. Policy Paper, 11, 1-72. Recuperado de https://bit.ly/2UBLezK

Motohashi, K. (1998). Innovation strategy and business performance of Japanese manufacturing firms. Economics of Innovation and New technology, 7(1), 27-52. doi:10.1080/10438599800000027

Mussa, A., Famá, R., \& Santos, J. O. dos (2012). A adição do fator de risco momento ao modelo de precificação de ativos dos três fatores de Fama \& French aplicado ao mercado acionário brasileiro. Revista de Gestão, 19(3), 453-471. doi:10.5700/rege473 
Mussa, A., Rogers, P., \& Securato, J. R. (2009). Modelos de retornos esperados no mercado brasileiro: Testes empíricos utilizando metodologia preditiva. Revista de Ciências da Administração, 11(23), 192-216. doi:10.5007/ 2175-8077.2009v11n23p192

Oliveira, M. O. R., Schossler, D. P., Campus, R. E., \& Luce, F. B. (2014). Ativos intangíveis e o desempenho econômico-financeiro: Comparação entre os portfólios de empresas tangível-intensivas e intangível-intensivas. Revista de Administração da UFSM, 7(4), 678-699. doi:10.5902/1983 465913552

Oliveira, M. R. G., Karvalho, K. S., Roma, C. M. S., \& Melo, F. V. S. (2011). Optimizing a portfolio investment: A study of assets Ibovespa the period 2009 to 2011. Revista Razão Contábil \& Finanças, 2(2), 1-14.

Pavitt, K., Steinmueller, W. E., Pettigrew, A., Thomas, H., \& Whittington, R. (2002). Technology in corporate strategy: Change, continuity and the information revolution. London: Sage.

Perez, M. M., \& Famá, R. (2004). Características estratégicas dos ativos intangíveis e o desempenho econômico da empresa. Encontro Anual da Associação Nacional de Pós-Graduação em Administração, Curitiba, PR, Brasil, 27.

Perez, M. M., \& Famá, R. (2006). Ativos intangíveis e o desempenho empresarial. Revista Contabilidade \& Finanças, 17(40), 7-24. doi:10.1590/ S1519-70772006000100002

Pulic, A. (2004). Intellectual capital - Does it create or destroy value? Measuring Business Excellence, 8(1), 62-68. doi:10.1108/13683040410524757

Reilly, R. F., \& Schweihs, R. P. (1998). Valuing intangible assets. Maidenhead: McGraw-Hill.

Rogers, P., \& Securato, J. R. (2009). Estudo comparativo no mercado brasileiro do Capital Asset Pricing Model (CAPM), modelo 3-fatores de Fama e French e Reward Beta Approach. Revista de Administração Contemporânea, 3(1), 159-180. Recuperado de https://bit.ly/2UU7J88

Ross, S. A., Westerfield, R. W., Jaffe, J., \& Lamb, R. (2015). Administração financeira. São Paulo: AMGH.

Sanvicente, A. Z. (2015). Relevância de prêmio por risco país no custo de capital das empresas. Revista de Administração Contemporânea, 19(1), 38-52. doi:10.1590/1982-7849rac2015140097.

Silva, R. B., Klotzle, M. C., Pinto, A. C. F., \& da Motta, L. F. J. (2018). R\&D investment and risk in Brazil. Global Finance Journal, 35, 106-114. doi:10.10 16/j.gfj.2017.08.003 
Silva, W. A. C., Pinto, E. A., \& Melo, A. A. de O. (2012). O CAPM e o CAPM condicional na precificação de índices acionários: Evidências de mudanças nos coeficientes estimados de 2005 a 2008. Revista de Administração Mackenzie, 13(2), 106-134. doi:10.1590/S1678-69712012000200005

Silva, W. C., Pinto, E. A., Melo, A. A. de O., \& Camargos, M. A. (2009). Análise comparativa entre o CAPM e o C-CAPM na precificação de índices acionários: Evidências de mudanças nos coeficientes estimados de 2005 a 2008. Encontro Brasileiro de Finanças, Porto Alegre, RS, Brasil, 9.

Sharpe, W. F. (1964). Capital asset prices: A theory of market equilibrium under conditions of risk. The Journal of Finance, 19(3), 425-442. doi:10.11 11/j.1540-6261.1964.tb02865.x

Sharpe, W. F., Alexander, G., \& Bailey, J. (1999). Investments (5th ed.). Englewood Cliffs, NJ: Prentice Hall.

Tambosi, E., Filho, Garcia, F. G., \& Bertucci, L. A. (2007). Testando empiricamente o CAPM condicional dos retornos esperados de carteiras dos mercados brasileiro, argentino e norte-americano. Revista de Gestão, 14(4), 63-75. doi:10.5700/issn.2177-8736.rege.2007.36614

Tidd, J. (2001). Innovation management in context: Environment, organization and performance. International Journal of Management Reviews, 3(3), 169-183. doi:10.1111/1468-2370.00062

Tidd, J., Bessant, J., \& Pavitt, K. (2005). Managing innovation: Integrating technological, managerial organizational change. New York: Wiley \& Sons.

Turchi, L. M. O., \& Morais, J. M. D. O. (2017). Políticas de apoio à inovação tecnológica no Brasil: Avanços recentes, limitações e propostas de ações. Brasília: Instituto de Pesquisa Econômica Aplicada. Recuperado de https://bit. ly/2vmfOye

Upton, W. S. (2001). Business and financial reporting. Challenges from the new economy. Recuperado de https://www.fasb.org/articles\&reports/sr_new_ economy.pdf

Villalonga, B. (2004). Intangible resources, Tobin's q, and sustainability of performance differences. Journal of Economic Behavior \& Organization, 54 (2), 205-230. doi:10.1016/j.jebo.2003.07.001

Werner, B. M., \& Souder, W. E. (2016). Measuring R\&D performance - State of the art. Research-Technology Management, 40(2), 34-42. doi:10.1080/0895 6308.1997.11671115

Wolf, M. (2017). Crise brasileira cria oportunidades. Valor.com. Recuperado de https://bit.ly/2UUzZYj 
Zanoteli, E. J., Amaral, H. F., \& Souza, A. A. de (2015). Intangible assets and the accounting representation crisis. Advances in Scientific and Applied Accounting, 8(1), 3-19. doi:10.14392/asaa.2015080101

\section{AUthor notes}

Amabele M. Oliveira, Faculdade de Economia, Administração e Contabilidade de Ribeirão Preto (FEA-RP), Universidade de São Paulo (USP); Vinícius M. Magnani, Faculdade de Economia, Administração e Contabilidade de Ribeirão Preto (FEA-RP), Universidade de São Paulo (USP); Júlia P. Tortoli, Departamento de Contabilidade, Universidade Cruzeiro do Sul (UCS); Anelise K. P. Figari, Faculdade de Economia, Administração e Contabilidade de Ribeirão Preto (FEA-RP), Universidade de São Paulo (USP); e Marcelo A. Ambrozini, Faculdade de Economia, Administração e Contabilidade de Ribeirão Preto (FEA-RP), Universidade de São Paulo (USP).

Amabele M. Oliveira is now audit assistant at KPMG Brazil; Vinícius M. Magnani is now professor at the Department of Accounting at Centro Universitário Moura Lacerda; Júlia P. Tortoli is now $\mathrm{PhD}$ student in Controllership and Accounting at Faculdade de Economia, Administração e Contabilidade de Ribeirão Preto (FEA-RP) at Universidade de São Paulo (USP); Anelise K. P. Figari is now professor at the Department of Accounting at Universidade Federal do Paraná (UFPR); \& Marcelo A. Ambrozini is now Associate Professor at Faculdade de Economia, Administração e Contabilidade de Ribeirão Preto (FEA-RP) at Universidade de São Paulo (USP).

Correspondence concerning this article should be addressed to Júlia P. Tortoli, Avenida Bandeirantes, 3900, Monte Alegre, Ribeirão Preto, São Paulo, Brazil, CEP 14040-900.

E-mail: jptortoli@usp.br

\section{EDITORIAL BOARD}

Editors-in-chief

Janette Brunstein

Silvia Marcia Russi de Domênico

Associated Editor

Michele Jucá

Technical Support

Vitória Batista Santos Silva

\section{EDITORIAL PRODUCTION}

Publishing Coordination

Jéssica Dametta

Layout Designer

Emap

Language Editor

Daniel de Almeida Leão

Graphic Designer

Libro 